\title{
Evidence for the presence of corrosive solution within corrosion products film in magnesium alloy ZK60
}

\author{
E. D. Merson ${ }^{\dagger, 1}$, V.A. Poluyanov ${ }^{1}$, P.N. Myagkikh ${ }^{1}$, D. L. Merson¹, A. Yu. Vinogradov ${ }^{2}$ \\ †Mersoned@gmail.com
}

${ }^{1}$ Institute of Advanced Technologies, Togliatti State University, Togliatti, 445667, Russia

${ }^{2}$ Department of Mechanical and Industrial Engineering, Norwegian University of Science and Technology - NTNU, Trondheim, N-7491 Norway

It has been recently suggested that it is the corrosion solution sealed within the corrosion products layer that can be the primary cause of pre-exposure stress corrosion cracking (PESCC) of Mg alloys. In the present study, we attempt to find additional evidence for the presence of the retained corrosive media in the corrosion products layer deposited on the surface of the ZK60 alloy. The samples of this alloy were pre-exposed to the corrosive solution for $1.5 \mathrm{~h}$ and then subjected to the thermal desorption analysis (TDA). The specimens were tested either immediately after pre-exposure or after the post-exposure immersion in $\mathrm{CCl}_{4}$ or storing in desiccator for $24 \mathrm{~h}$. During the immersion in $\mathrm{CCl}_{4}$, the volume of hydrogen desorbing from the samples was assessed. The main finding of the present study lies in that the corrosion reaction remains within ZK60 samples even after their extraction from the corrosive solution. This is evidenced by the extensive hydrogen desorption which continued and not ceased even after 24 hours after pre-exposure. It is established that the largest part of this hydrogen cannot be detected by short TDA of the sample right after pre-exposure to corrosive media, thus it should be produced in-situ during the immersion in $\mathrm{CCl}_{4}$. Considering that $\mathrm{CCl}_{4}$ is inert with respect to $\mathrm{Mg}$, it is concluded that the corrosion reaction producing hydrogen can be caused only by aggressive media retained within the corrosion products layer.

Keywords: Mg alloys, pre-exposure stress corrosion cracking, hydrogen, corrosion products, thermal desorption analysis.

\section{Свидетельство присутствия коррозионного раствора в слое продуктов коррозии магниевого сплава ZK60}

\author{
Мерсон Е. Д. ${ }^{\dagger, 1}$, Полуянов В. А. ${ }^{1}$, Мягких П. Н. ${ }^{1}$, Мерсон Д. Л. ${ }^{1}$, Виноградов А. Ю. ${ }^{2}$ \\ ${ }^{1}$ Научно-исследовательский институт прогрессивных технологий Тольяттинского государственного университета, \\ Тольятти, 445667, Россия \\ ${ }^{2}$ Факультет машиностроения и промышленной инженерии, Норвежский университет науки и технологий — NTNU, \\ Тронхейм, N-7491 Норвегия
}

Недавно было высказано предположение о том, что коррозионный раствор, запечатанный в слое продуктов коррозии, может быть основной причиной предэкспозиционного коррозионного растрескивания под напряжением (PESCC) магниевых сплавов. В настоящей работе предпринята попытка найти дополнительные доказательства наличия остаточной агрессивной среды в слое продуктов коррозии, осаждающихся на поверхности сплава ZК60. Образцы этого сплава предварительно выдерживали в коррозионном растворе в течение 1.5 ч, а затем подвергали термодесорбционному анализу (ТДА), который проводили либо сразу после предварительной выдержки образца, либо после его погружения в $\mathrm{CCl}_{4}$ или вылеживания в эксикаторе в течение 24 ч. При погружении в $\mathrm{CCl}_{4}$ оценивали объем водорода выделяющегося из образцов. Основной вывод настоящего исследования заключается в том, что протекание коррозионной реакции продолжается в образцах ZK60 даже после их извлечения из агрессивного раствора. Об этом свидетельствует интенсивная десорбция водорода, которая не прекращается даже через 24 часа после предварительной выдержки. Установлено, что большая часть этого водорода не может быть обнаружена в ходе относительно короткого ТДА, который проводится сразу после предварительной выдержки образца в агрессивной среде. Следовательно, данный водород должен образовываться in-situ, т. е. непосредственно в процессе вылеживания образца в $\mathrm{CCl}_{4}$. Учитывая, что $\mathrm{CCl}_{4}$ инертен по отношению к $\mathrm{Mg}$, сделан вывод, что коррозионная реакция с образованием водорода может быть вызвана только агрессивной средой, удерживаемой в слое продуктов коррозии.

Ключевые слова: магниевые сплавы, предэкспозиционное коррозионное растрескивание под напряжением, водород, продукты коррозии, термодесорбционный анализ. 


\section{Introduction}

Magnesium alloys are highly susceptible to stress corrosion cracking (SCC), which is a frequent reason of the loss of integrity and brittle in-service failures of load-bearing metallic parts operating in aggressive environments [1]. Thus, SCC is a serious safety-related issue impeding wider uptake of Mg-based alloys, which are considered by industry as structural materials for low-weight elements of aerospace and automobile vehicles [2] as well as bio-compatible materials for temporary medical implants [3]. However, up to date, there are no practically viable approaches to the chemical and microstructural design of SCC-resistant Mg alloys. It is largely and unfortunately because of the insufficient understanding of the mechanisms responsible for the nucleation and propagation of cracks in $\mathrm{Mg}$ under the simultaneous action of external loads and corrosion-active environment.

The overall $\mathrm{Mg}$ corrosion reaction in aqueous solutions reads as [4]:

$\mathrm{Mg}+2 \mathrm{H}_{2} \mathrm{O} \rightarrow \mathrm{Mg}^{2+}+2\left(\mathrm{OH}^{-}\right)+\mathrm{H}_{2} \rightarrow \mathrm{Mg}(\mathrm{OH})_{2}+\mathrm{H}_{2}$

The partial cathodic reaction for a neutral or alkaline solution is evolution of hydrogen:

$$
2 \mathrm{H}_{2} \mathrm{O}+2 \mathrm{e}^{-} \rightarrow \mathrm{H}_{2}+2 \mathrm{OH}^{-}
$$

The overall anodic reaction is dissolution of $\mathrm{Mg}$ :

$$
\mathrm{Mg} \rightarrow \mathrm{Mg}^{++}+2 \mathrm{e}
$$

The SCC of Mg alloys is most often attributed to anodic dissolution (AD), hydrogen embrittlement (HE) or to the synergistic action of both these phenomena $[1,5]$. While AD is an intrinsic process occurring during the interaction of the metal with corrosive media, HE is believed to be induced by hydrogen evolving via the cathodic corrosion reaction and presumably absorbed by the metal in a diffusible atomic form.

The understanding of the role of hydrogen and corrosive solution in SCC is crucially important for choosing the most effective strategy for the microstructural design of $\mathrm{Mg}$ alloys to diminish their susceptibility to SCC. The phenomenon known as PESCC has long been considered as strong evidence that it is HE that governs SCC in Mg alloys [6,7]. PESCC is referred to the embrittlement, which appears after immersion of the metal in a corrosive solution followed by tensile testing in an inert environment. Since the corrosive solution does not interact directly with the metal during mechanical testing, and, consequently, the effects associated with $\mathrm{AD}$ can be excluded, PESCC is commonly attributed to hydrogen being absorbed by the metal during pre-exposure to corrosive media [6-10]. However, this interpretation of the origin of PESCC has been challenged by the present authors recently on the basis of several new experimental findings reported in [11-13]. Specifically, it was found that neither the loss in ductility nor the appreciable concentration of diffusible hydrogen is observed in $\mathrm{Mg}$ alloys pre-exposed to the corrosive solution if the corrosion products layer is removed from the specimens' surface prior to the subsequent tensile testing in air [12,13]. These findings imply that PESCC should be attributed merely to the corrosion products layer. It was concluded that the role of diffusible hydrogen was minor because of insufficient penetration of this hydrogen into the $\mathrm{Mg}$ matrix during corrosion. Furthermore, it was suggested that PESCC could be caused by the retained corrosive solution, which was supposed to be sealed within the discontinuities in the corrosion products [11]. This was indirectly evidenced by the abundant presence of the corrosion products on the peripheral parts of the fracture surface as well as inside the secondary cracks in the pre-exposed specimens, which did not interact with external corrosive media during tensile testing in air. The present study is aimed at gaining a deeper insight into the mechanism controlling the SCC phenomenon. Additional evidence for the presence of the aggressive solution in the corrosion products layer deposited on the surface of $\mathrm{Mg}$ alloys is needed and sought in the present work. Being sealed within the corrosion products, the corrosion solution is expected to cause the corrosion reaction that should be accompanied by $\mathrm{AD}$ of $\mathrm{Mg}$ and cathodic reduction of hydrogen. To this end, the primary task is to confirm whether these reactions occur or not in the Mg alloy samples, which had been pre-exposed to corrosive media.

\section{Experimental}

The cylindrical samples of $6 \mathrm{~mm}$ diameter and $30 \mathrm{~mm}$ length were machined from the hot-extruded bar of the commercial alloy ZK60, which is known to be strongly susceptible to PESCC. The chemical composition, microstructure and mechanical properties of this alloy as well as its susceptibility to SCC and PESCC at various conditions, were documented in detail in our previous reports [11-16]. The samples were immersed in the aqueous corrosive solution of $4 \% \mathrm{NaCl}+4 \% \mathrm{~K}_{2} \mathrm{Cr}_{2} \mathrm{O}_{7}$ at the open-circuit potential and ambient temperature of $24^{\circ} \mathrm{C}$. No external stress was applied to the samples during preimmersion. Two samples were submerged at the same time. However, a separate beaker with the corrosion solution was used for each of them. After 1.5 hours of exposure, the samples were removed from corrosive media, cleaned with ethanol and dried with compressed air.

\subsection{Hydrogen evolution at room temperature}

Within 5 minutes after these procedures, one sample was subjected to the thermal desorption analysis (TDA), while the other one was immersed for 24 hours in a burette filled with chemically pure $\mathrm{CCl}_{4}$ as is schematically shown in Fig. 1 to measure the volume of hydrogen-gas desorbed from the sample at room temperature and to assess the kinetics of hydrogen evolution. The similar hydrogen evolution technique is frequently utilized to evaluate the corrosion rate of $\mathrm{Mg}$ alloys [4,17]. Since one mole of dissolved $\mathrm{Mg}$ produces one mole of $\mathrm{H}_{2}$, the corrosion rate can be evaluated by the volume of hydrogen gas accumulated in the upper end of the burette $[4,17]$. It is generally accepted that $\mathrm{H}_{2}$ is the only gas that can evolve from the sample [17]. The main difference of the experimental approach used in the present study from the conventional one is that, instead of the corrosive solution, the burette was filled with $\mathrm{CCl}_{4}$, which is inert to $\mathrm{Mg}$. This enables ensuring that hydrogen gas evolving from the sample is (i) hydrogen, which has been already produced during the pre-exposure of the sample to corrosive media, and/or it is (ii) new "nascent" hydrogen, which is produced in-situ due to the corrosion reaction of the sample with corrosive media retained and sealed within the corrosion products. 


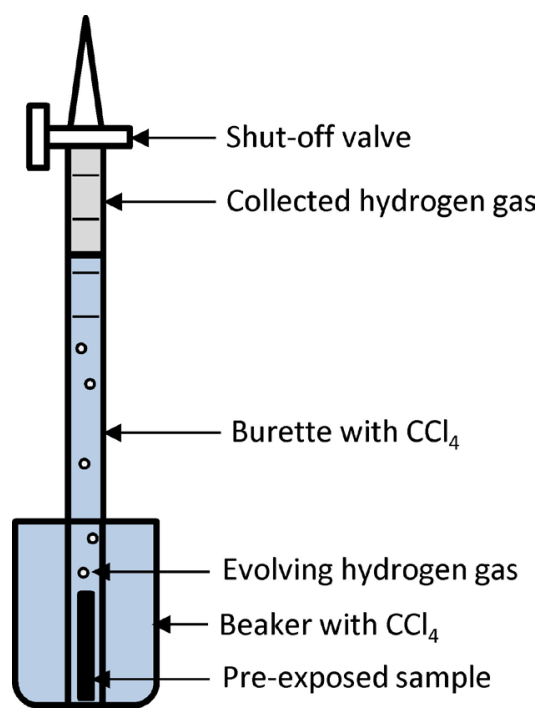

Fig. 1. (Color online) Experimental setup for evaluation of hydrogen evolution from the sample pre-exposed to the corrosion solution.

The volume of hydrogen gas accumulated in the burette have been measured every 30 min within 24 hours to characterize the kinetics of hydrogen evolution. When the experiment was finished, the total volume of hydrogen was measured; the sample was extracted from the burette, dried with compressed air and subjected to TDA to evaluate the residual concentration of hydrogen in the sample. For the reference, the similar pre-exposed sample of the same alloy was stored in a desiccator for 24 hours immediately after pre-exposure; it was then subjected to TDA too. To assess the reproducibility, all the experiments described above have been repeated twice.

\subsection{Thermal desorption analysis}

TDA of both samples was performed by the hot-extraction method by the Galileo G8 (Bruker) gas-analyzer. The hotextraction was conducted in the flux of $99.999 \%$ pure nitrogen gas. The procedure of hot-extraction included: (i) heating the sample from 24 to $450^{\circ} \mathrm{C}$ with the constant heating rate of $38^{\circ} \mathrm{C} / \mathrm{min}$, and (ii) isothermal baking at $450^{\circ} \mathrm{C}$ during $600 \mathrm{~s}$ followed by (iii) free cooling in the furnace during $600 \mathrm{~s}$ to stabilize the signal from the detector at the background level. The reasons for choosing this gas-analysis schedule have been described elsewhere [16]. The important point to note is that the gas-analyzer is equipped with a selective filtration system that absorbs the water vapour, which can possibly evolve from the sample during heating. Thus, until the $\mathrm{H}_{2} \mathrm{O}$ molecules are decomposed into oxygen and hydrogen, water stored within the sample does not affect the hydrogen signal of the thermal conductivity detector built-in in the gas-analyzer. To verify the effectiveness of this filtration system, the quartz tube abundantly wet with distilled water was subjected to gas analysis according to the same protocol as described above. Throughout the test, the signal of hydrogen was close to the background level. Thus, the hydrogen evolution from evaporating water was confirmed negligible. This means that if the liquid corrosive solution is sealed within the preexposed sample, it cannot be detected by the gas-analysis, except the part of this liquid that is decomposed right during the gas analysis.

\subsection{Metallographic study}

The metallographic examination of the sample was conducted immediately after pre-exposure in corrosion solution. The cross-section of this sample was hot-mounted in epoxy resin, grounded by emery papers wet with alcohol and polished with water-free alcohol-based diamond suspensions. The investigation of the cross-sections was done by the scanning electron microscope (SEM) JCM-6000 (JEOL).

\section{Results and discussion}

\subsection{Metallographic study}

The metallographic examination showed the presence of numerous gas bubbles "frozen" within the epoxy resin around the surface of the pre-exposed sample. Large bubbles are found attached to corrosion cavities. Beneath the bubbles, one can see the friable layer of corrosion products containing numerous cracks and other discontinuities, which can potentially serve as collectors for corrosive media. It can also be observed in Fig. 2 that corrosion occurred inhomogeneously; the net of microscopic cracks is clearly seen. These cracks are formed presumably along the grain boundaries; at least, one can notice that the size and the shape of the fragments surrounded by these micro-cracks are comparable to those of grain size, which has been shown to be of $3 \mu \mathrm{m}$ diameter on average in this alloy.

\subsection{Hydrogen evolution at room temperature}

The experiments showed that the samples, which were immersed in $\mathrm{CCl}_{4}$ right after pre-exposure in corrosive media, demonstrated extensive desorption of hydrogen. This was witnessed by numerous bubbles emanating from the sample; these bubbles were visible even by the naked eye. This hydrogen gas accumulated in the upper end of the burette, shifting the $\mathrm{CCl}_{4}$ liquid downward. The measurement of the volume of extracted gas according to the displacement of $\mathrm{CCl}_{4}$ level showed that evolution of hydrogen occurs throughout the entire experiment during 24 hours, see Fig. 3. However, it follows from Fig. 3, that the rate of hydrogen desorption decreases strongly with time, and it is significantly larger during the first two hours after pre-exposure. Besides, after approximately 2 hours of immersion in $\mathrm{CCl}_{4}$, the desorption of hydrogen tends to occur sporadically with the burst extractions of relatively large gas portions followed by the fairly long waiting time intervals when hydrogen evolution was practically not detectable. It is established that, on average, $2 \mathrm{ml}$ or $109 \mathrm{ppm}$ of hydrogen were desorbed from the pre-exposed samples being immersed in $\mathrm{CCl}_{4}$ during 24 hours, c. f., Table 1 .

\subsection{Thermal desorption analysis}

The hydrogen extraction curves obtained during TDA of the pre-exposed samples are represented in Fig. 4. The shape of these curves suggests that they appear because of the 


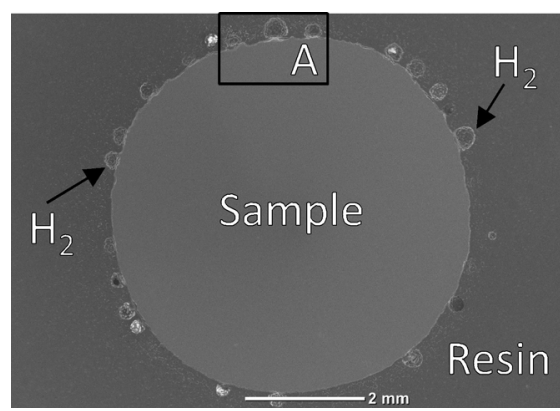

a

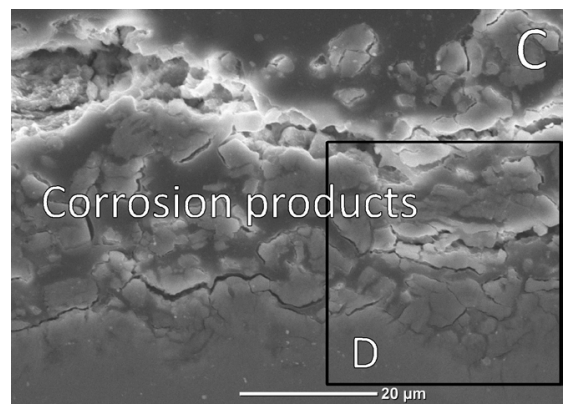

$\mathrm{d}$

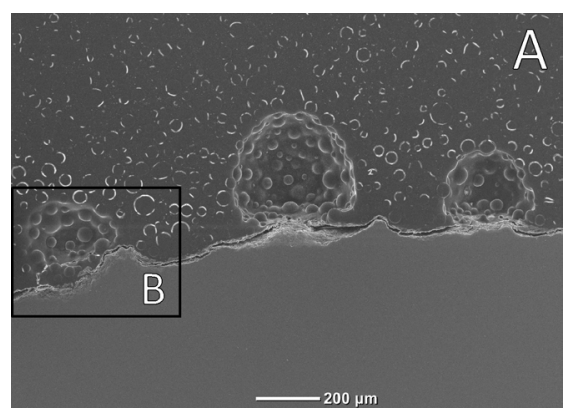

b

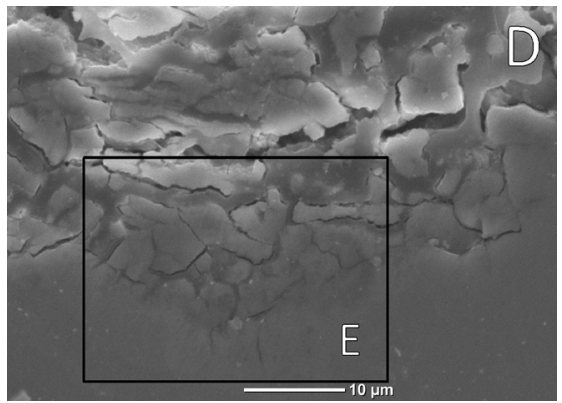

e

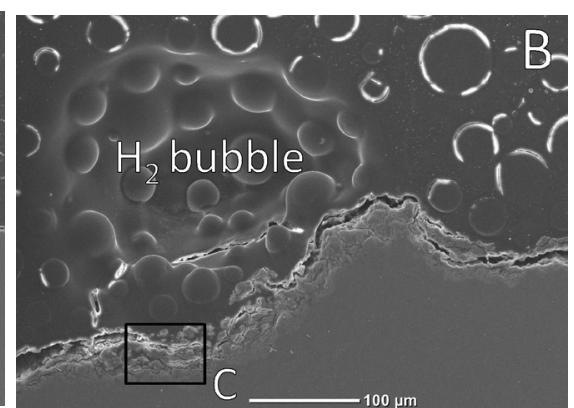

c

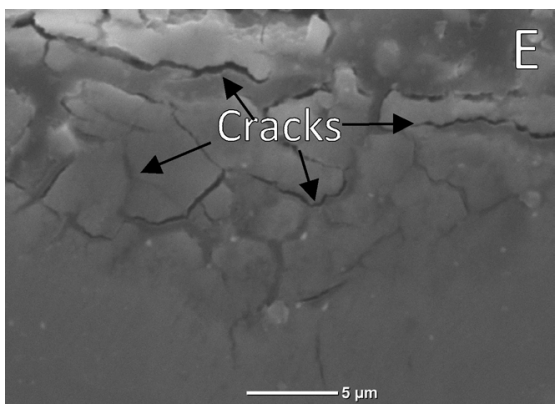

$\mathrm{f}$

Fig. 2. The metallographic SEM images of the sample of the alloy ZK60 mounted in epoxy resin right after pre-exposure to corrosive media. The magnified views of the areas outlined by the letter-labeled frames "A-E" in (a-e) are represented in (b-f), respectively.

superposition of several individual peaks. Although the identification of the exact nature of each of these peaks is still challenging, it was established in our previous studies that all these peaks are attributed to the components of the corrosion products layer. In particular, this was evidenced by the fact that after the removal of corrosion products from the surface of the pre-exposed ZK60 specimens, all these peaks vanished almost completely. Besides, it is obvious from the results of the previous and present studies that the first peak corresponding to the lowest temperature on the extraction curve, peak 1 in Fig. 4, is associated with gaseous hydrogen accumulated within the discontinuities of the corrosion products layer and can freely evolve from the samples at room temperature. It is underpinned by the observation that this peak is absent on the extraction curves obtained from the

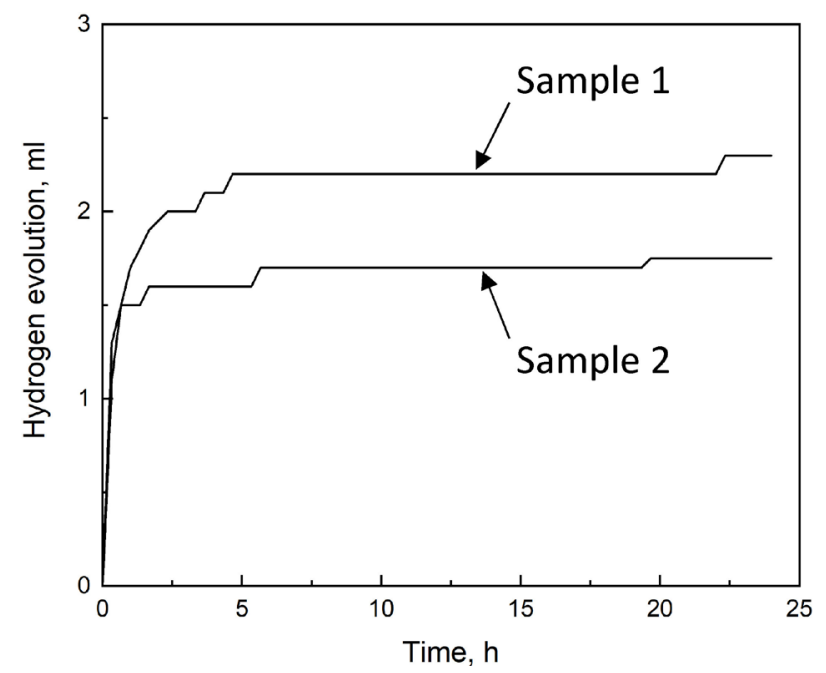

Fig. 3. Evolution of hydrogen from the pre-exposed samples of the alloy ZK60 being immersed in $\mathrm{CCl}_{4}$ for 24 hours. pre-exposed samples after 24 hours of storing in $\mathrm{CCl}_{4}$ or in the desiccator, c. f., Fig. 4.

According to the results of TDA, the room temperature storing of the pre-exposed samples in desiccator results in the decrease of hydrogen concentration from $88.6 \pm 5.3$ to $75.6 \pm 1.2$. Thus, they lose only about $13 \mathrm{ppm}$ of hydrogen during storing in desiccator, whereas, according to the results of hydrogen evolution experiment with the burette-based setup described above, almost 9 times of magnitude higher concentration of hydrogen is desorbed from the counterpart pre-exposed samples being immersed in $\mathrm{CCl}_{4}$ during the same time and at the same temperature. Obviously, this apparent contradiction cannot be explained by different environments in which the samples were stored after pre-exposure since both $\mathrm{CCl}_{4}$ and dry air are inert to $\mathrm{Mg}$, and there is no reason

Table 1. Concentration of hydrogen desorbed from the pre-exposed samples of the alloy ZK60 during TDA and during immersion in $\mathrm{CCl}_{4}$.

\begin{tabular}{|c|c|c|}
\hline Sample & $\begin{array}{c}\text { Volume / concentration of } \\
\text { hydrogen desorbed at room } \\
\text { temperature during } 24 \mathrm{~h} \\
\text { immersion in } \mathrm{CCl}_{4}, \mathrm{ml} / \mathrm{ppm}\end{array}$ & $\begin{array}{c}\text { Concentration } \\
\text { of hydrogen } \\
\text { measured by } \\
\text { TDA, ppm }\end{array}$ \\
\hline $\begin{array}{c}\text { Pre-exposure to } \\
\text { corrosion solution }\end{array}$ & $88.6 \pm 5.3$ \\
\hline $\begin{array}{c}\text { Pre-exposure } \\
\text { to corrosion } \\
\text { solution and } 24 \mathrm{~h} \\
\text { immersion in } \mathrm{CCl}\end{array}$ & $2.0 \pm 0.3 / 108.6 \pm 14.8$ & $98.9 \pm 5.7$ \\
\hline $\begin{array}{c}\text { Pre-exposure to } \\
\text { corrosion solution } \\
\text { and } 24 \mathrm{~h} \text { storing in } \\
\text { desiccator }\end{array}$ & & $75.6 \pm 1.2$ \\
\hline
\end{tabular}




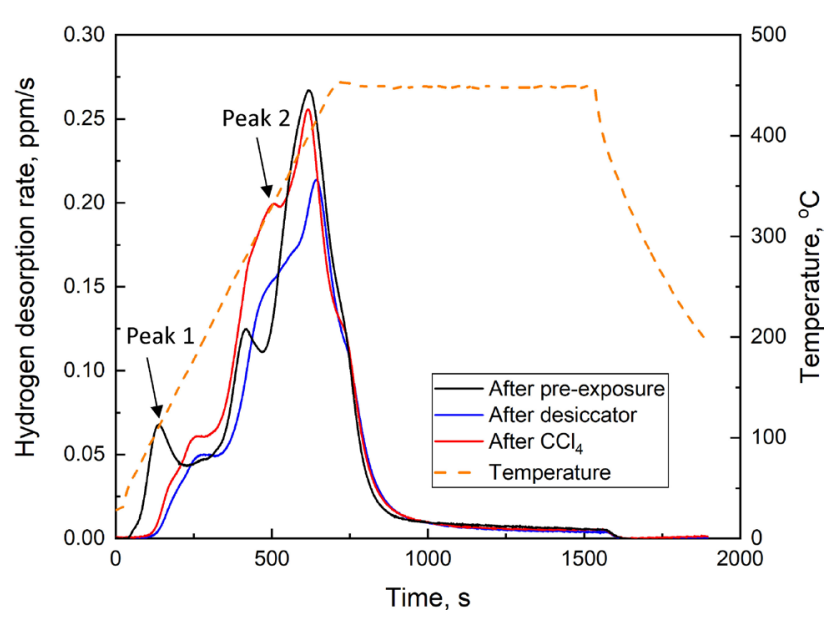

Fig. 4. (Color online) TDA extraction curves of hydrogen from the samples of the ZK60 alloy tested immediately after pre-exposure in corrosive media as well as after pre-exposure followed by the storing in $\mathrm{CCl}_{4}$ or in desiccator for 24 hours.

to expect any additional hydrogen to be produced by the interaction of $\mathrm{Mg}$ with $\mathrm{CCl}_{4}$. The most plausible explanation for the obtained results is that the largest fraction of hydrogen evolved from the pre-exposed sample during immersion in $\mathrm{CCl}_{4}$ is produced in-situ due to the interaction of $\mathrm{Mg}$ matrix with the retained corrosive media being sealed within the corrosion products. If the gas analysis is conducted right after pre-exposure, the most part of this "nascent" hydrogen cannot be detected by short TDA lasting for approximately $30 \mathrm{~min}$, because this hydrogen remains to be part of the $\mathrm{H}_{2} \mathrm{O}$ molecules, which are filtered out by filter system of gasanalyzer.

As follows from the results of TDA represented in Table 1, the hydrogen concentration corresponding to the samples, which were immersed in $\mathrm{CCl}_{4}$ is higher than that of the preexposed samples analyzed right after pre-exposure as well as after storing in desiccator. Presumably, this can be due to the fact that $\mathrm{CCl}_{4}$ can promote the formation of magnesium hydride $\mathrm{MgH}_{2}$ [18], which is supposed to be the component of corrosion products. A certain part of hydrogen evolving during corrosion reaction can be probably consumed for the formation of the hydride both in $\mathrm{CCl}_{4}$ as well as in dry air of desiccator. However, in the presence of $\mathrm{CCl}_{4}$ the more significant amount of hydride formed in this way is expected. It can be seen in Fig. 4 that the extraction curve of the preexposed samples, which were additionally immersed in $\mathrm{CCl}_{4}$, is featured by the remarkably higher peak, c.f., peak 2 in Fig. 4, at the temperature of $330^{\circ} \mathrm{C}$ if compared to the curves of two other kinds of samples. This temperature is very close to the decomposition temperature of $\mathrm{MgH}_{2}$ [18]. Nevertheless, the identification of the nature of individual peaks on the extraction curves obtained by TDA of the corroded Mg samples was beyond the scope of the present investigation and requires additional comprehensive study.

\section{Conclusions}

The results of the present study show that abundant evolution of hydrogen gas occurs from the corroded samples of the ZK60 alloy at least during 24 hours after pre-exposure to the aqueous $4 \% \mathrm{NaCl}+4 \% \mathrm{~K}_{2} \mathrm{Cr}_{2} \mathrm{O}_{7}$ solution. The greatest part of this hydrogen cannot be detected by the short thermal desorption analysis if this analysis is conducted immediately after pre-exposure. The observed behaviour strongly supports the hypothesis that the active corrosion reaction occurs at the specimen surface due to the corrosion solution retained and sealed within the discontinuities of the corrosion products layer.

Acknowledgments. Financial support from the Russian Science Foundation through the grant-in-aid No. 18-19-00592 is gratefully appreciated.

\section{References}

1. N. Winzer, A. Atrens, G. Song, E. Ghali, W. Dietzel, K. U. Kainer, et al. Adv. Eng. Mater. 7, 659 (2005). Crossref

2. B. Landkof. Magnesium Alloys and their Applications, Wiley, Weinheim, FRG (2000). Crossref

3. S. Jafari, S. E. Harandi, R. K. Singh Raman. JOM. 67, 1143 (2015). Crossref

4. A. Atrens, G. L. Song, M. Liu, Z. Shi, F. Cao, M. S. Dargusch. Adv. Eng. Mater. 17, 400 (2015). Crossref

5. M. Kappes, M. Iannuzzi, R. M. Carranza. J. Electrochem. Soc. 160, C168 (2013). Crossref

6. D. G. Chakrapani, E. N. Pugh. Metall. Trans. A. 7, 173 (1976). Crossref

7. M. Kappes, M. Iannuzzi, R. M. Carranza. Corrosion. 70, 667 (2014). $\underline{\text { Crossref }}$

8. R. S. Stampella, R. P. M. Procter, V. Ashworth. Corros. Sci. 24, 325 (1984). Crossref

9. M. Bobby Kannan, W. Dietzel. Mater. Des. 42, 321 (2012). Crossref

10. K. Chen, Y. Lu, H. Tang, Y. Gao, F. Zhao, X. Gu, et al. Acta Biomater. 113, 627 (2020). Crossref

11. E. Merson, V. Poluyanov, P. Myagkikh, D. Merson, A. Vinogradov. Mater. Sci. Eng. A. 830, 142304 (2022). $\underline{\text { Crossref }}$

12. E. Merson, V. Poluyanov, P. Myagkikh, D. Merson, A. Vinogradov. Acta Mater. 205, 116570 (2021). Crossref

13. E. Merson, V. Poluyanov, P. Myagkikh, D. Merson, A. Vinogradov. Mater. Sci. Eng. A. 806, 140876 (2021). Crossref

14. E. Merson, V. Poluyanov, P. Myagkikh, D. Merson, A. Vinogradov. Mater. Sci. Eng. A. 772, 138744 (2020). Crossref

15. E.D. Merson, V.A. Poluyanov, P.N. Myagkikh, D. L. Merson, A. Y. Vinogradov. Lett. Mater. 10 (1), 94 (2020). (in Russian) [Е.Д. Мерсон, В.А. Полуянов, П. Н. Мягких, Д. Л. Мерсон, А. Ю. Виноградов. Письма о материалах. 10 (1), 94 (2020).] Crossref

16. E. Merson, P. Myagkikh, V. Poluyanov, D. Merson, A. Vinogradov. Mater. Sci. Eng. A. 748, 337 (2019). Crossref

17. G. Song, A. Atrens, D. StJohn. An Hydrogen Evolution Method for the Estimation of the Corrosion Rate of Magnesium Alloys. In: Magnes. Technol. John Wiley \& Sons, Inc., Hoboken, NJ, USA (2001) pp. 254-262. Crossref

18. V.A. Yartys, M.V. Lototskyy, E. Akiba, R. Albert, V.E. Antonov, J. R. Ares, et al. Int. J. Hydrogen Energy. 44, 7809 (2019). $\underline{\text { Crossref }}$ 